\title{
The Effect of Estrogen Treatment on Eccentric Exercise-Induced Damage in Rat Kidneys
}

\author{
Zinnur GEREK 'o İsmail MALKOÇ ${ }^{2}$ Seçil Nazife PARLAK ${ }^{3}$ \\ ${ }^{1}$ Department of Physical Education and Sports Sciences, Ataturk University, Physical Education and Sport Academy, \\ TR-25240 Erzurum - TURKEY \\ 2 Department of Anatomy, Ataturk University, Faculty of Medicine, TR-25240 Erzurum - TURKEY \\ ${ }^{3}$ Department of Histology of and Embryology, Ataturk University, Faculty of Medicine, TR-25240 Erzurum - TURKEY
}

KVFD-2015-13999 Received: 07.07.2015 Accepted: 29.09.2015 Published Online: 01.10.2015

\begin{abstract}
The aim of this study was to examine the effects of anabolic steroids on eccentric exercise-induced kidney tissue, using biochemical and histological methods. Sprague Dawley male rats $(n=36)$ were equally divided into the estrogen (17- $\beta$ Estradiol, $10 \mathrm{mg} / \mathrm{kg}$ per day)induced and non estrogen-induced groups. Both groups were subdivided into as rest groups $(n=6)$, and as exposed to the eccentric exercise groups $(n=12)$ that were also subdivided into decapitated one hour $(n=6)$ and 48 hour $(n=6)$ groups after eccentric exercise. Histopathological effects of estrogen treatment on eccentric exercise-induced rat kidney tissues were seen. The histopathological results revealed that hemorrhage, endothelium-dependent vasodilatations and degenerative changes in proximal tubules, glomeruli, and connective tissue in the estrogen-given and estrogen-given plus eccentric exercise groups. Distal tubule degenerations and dilatations with peritubular capillary dilatations and polymorphonuclear leucocyte (PMNL) infiltrations to connective tissue in eccentric exercise and eccentric exercise plus estrogen-given groups were detected but also it was noticeable decreases in PMNL infiltrations in estrogen-given groups. Biochemical results showed oxidative stress in experimental groups except Control group. It has been concluded that estrogen could not have been effective for preventing eccentric exercise-induced kidney damage and might have toxic effects on kidney tissues on clinical practice however anti-inflammatory effect on kidney tissue detected. It has been requested further investigation.
\end{abstract}

Keywords: Eccentric exercise, Estrogen, Kidney, Rat

\section{Östrojen Tedavisinin Eksantrik Egzersiz Uygulanan Sıçan Böbrekleri Üzerinde Oluşturduğu Hasara Etkisi}

\begin{abstract}
Özet
Bu çalışmanın amacı, anabolik steroidlerin etkilerini eksantrik egzersiz uygulanan sıçanların böbrek dokusunda, biyokimyasal ve histolojik yöntemler kullanarak incelemektir. Sprague Dawley erkek fareler $(n=36)$, eşit şekilde östrojen uygulanan (17- $\beta$ Estradiol, günde $10 \mathrm{mg} / \mathrm{kg}$ ) ve östrojen uygulanmayan iki gruba ayrıldı. Bu iki grup da kendi aralarında eksantrik egzersiz uygulanan $(\mathrm{n}=12$ ) ve uygulanmayan $(n=6)$ olmak üzere iki alt gruba ayrıldı. Daha sonra eksantrik egzersiz uygulanan gruplarda egsersiz işleminde bir saat $(n=6)$ ve 48 saat $(n=6)$ sonra dekapite edilerek iki alt gruba ayrıldı. Östrojenin eksantrik egzersiz uygulanan sıçanların böbrek dokusunda histopatolojik etkileri olduğu görüldü. Östrojen ve östrojen+eksantrik egzersiz uygulanan grupların böbrek dokularında hemoraji, damarlarda endotel bağımlı vazodilatasyonlar ve proksimal tübüller, glomerüller ve bağ dokusunda da dejeneratif değişiklikler saptandı. Eksantrik egzersiz ve eksantrik egzersiz+östrojen uygulanan gruplarda distal tübüllerde dejenerasyonlar ve dilatasyonlar, peritübüler kapiller dilatasyonları ve bağ dokuya polimorfonükleer lökosit (PMNL) sızıntıların saptandı. Bununla birlikte östrojen uygulanan gruplarda PMNL infiltrasyonunda dikkat çekici bir azalma izlendi.. Biyokimyasal sonuçlar Kontrol grubu dışındaki diğer deneysel gruplarda oksidatif stress olduğunu gösterdi. Östrojenin eksantrik egzersize bağlı böbrek hasarı önlemede anti-inflamatuar etkisinin görülmesine rağmen yeterli derecede etkin olamayabileceği ve klinik uygulamalarda böbrek dokuları üzerinde toksik etkileri olabileceği sonucuna varılmıştır. Bu alanda ileriye yönelik daha ayrıntılı çalışmalar yapılabilir.
\end{abstract}

Anahtar sözcükler: Böbrek, Eksantrik egzersiz, Östrojen, Sıçan

\footnotetext{
İletişim (Correspondence)

+905058001816

seeparlak@gmail.com
} 


\section{INTRODUCTION}

Physical exercise is an activity that improves and maintains physical fitness, overall health and wellness. Regular moderate exercise has positive effects on the immune system, cardiovascular, nerve, endocrine and renal systems ${ }^{[1-5]}$. Beside this, doing too much exercise may be harmful. Without enough rest, striated or heart muscle tissue damages may occur that can cause dynamic upper respiratory tract or heart rhythm abnormalities and etc ${ }^{[6,7]}$. Otherwise, many negative effects like proteinuria, hematuria and changes on renal hemodynamics that may cause acute renal failure may occur ${ }^{[8,9]}$.

Estrogens, a group of compounds, which are female sex hormones, have a major role for both menstrual and ovarian cycles. Estrogens bind to and activate the estrogen receptors (ER) which moderate the expression of many genes when they enter the cell ${ }^{[10-12]}$. The presence of the ER determines the actions of estrogens in the cell ${ }^{[13]}$. Estrogens play several important roles in protein synthesis, coagulation, lipid metabolism and structural changes like promoting development of female secondary sex characteristics, accelerating metabolism, increasing fat stores or stimulating endometrial growth $[10,11,14,15]$. There are also many benefits of estrogens such as preventing role in atherosclerosis via vascular protective action ${ }^{[14,15]}$ and immunological role with anti-inflammatory properties providing migration of polymorphonuclear leucocytes (PMNLs) ${ }^{[15]}$. Beside this, some researches revealed that estrogen administration can cause various types of DNA damage in estrogen-responsive tissues via free radicals and lipid hydroperoxide-mediated DNA modifications ${ }^{[16]}$.
Researches on the role of estradiol on eccentic exerciseinduced rat kidney tissues are limited. The aim of the present study was to assess the role estrogen usage on eccentric exercise-induced rat kidney tissues.

\section{MATERIAL and METHODS}

\section{Animals}

Thirty six male, 12 weeks old Sprague Dawley rats, weighing $245 \pm 22.99 \mathrm{~g}$ were kept in facilities accredited by international guidelines. All experimental designs and trials were conducted with the approval of the Instutional Animal Care and Use Committee of Ataturk University (ATADEM-Approval No: B.30.2.ATA.0.23.71-514; 22.04.2011). The rats in groups of six per cage were housed in environmentally controlled room in the conditions of constant temperature/humidity with reversed a 12-hour light/dark cycles. They were allowed free access to food (AIN-93 puried rodent diet) and water. After one day of acclimatization, the animals were divided randomly into six groups, as shown in Fig. 1.

\section{Drug Administration}

Animals were injected daily subcutaneously with $\beta$-estradiol 3-benzoate $(10 \mu \mathrm{g} 0.1 \mathrm{ml}$ of sunflower oil$1.100 \mathrm{~g}$ body wt-1) ${ }^{[17]}$ for 30 consecutive days and following the final injection after $24 \mathrm{~h}$ the animals were acutely exercised ${ }^{[18,19]}$.

\section{Eccentric Exercise Protocol}

A motorized rodent treadmill having an electric shock

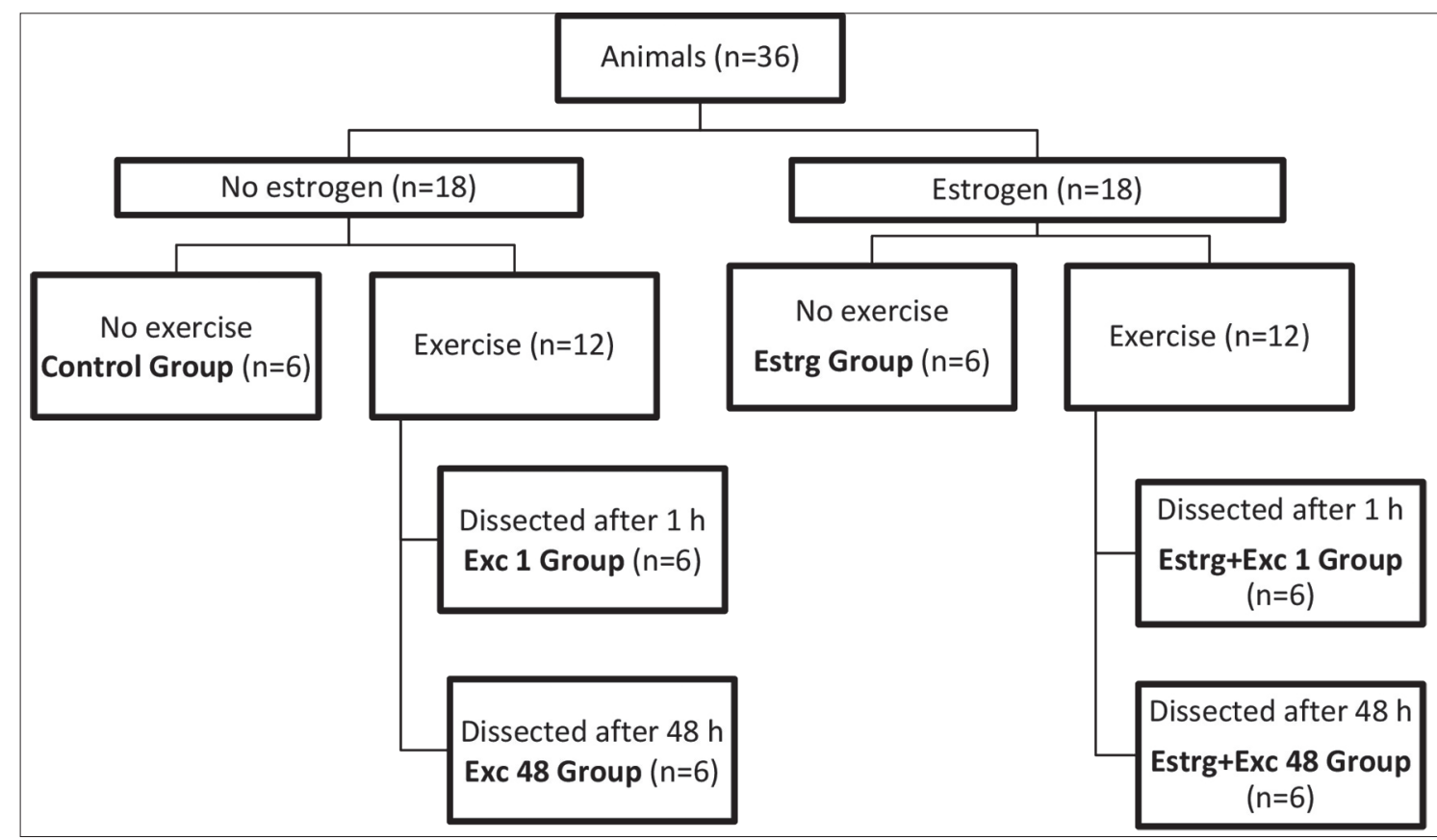

Fig 1. Experimental protocols of all groups of study Şekil 1. Tüm gruplarda uygulanan deneysel protokoller 
grid was used for modeling the acute exercise. Animals were forced to run on a $15 \%$ downhill grade at $20 \mathrm{~m} \cdot \mathrm{min}^{-1}$ speed for $90 \mathrm{~min}{ }^{[20]}$. After $1 \mathrm{~h}$ or $48 \mathrm{~h}$ exercise management all rats were decapitated and dissected. Then their kidney tissues were removed and kept in proper conditions for histological procedures.

\section{Biochemical Analyses}

Rat kidney tissues were collected and homogenized with liquid nitrogen in a mortar and were kept at $-80^{\circ} \mathrm{C}$ for the biochemical investigation. Measuring malondialdehyde (MDA), superoxide dismutase (SOD), catalase (CAT), glutathione peroxidase (GPx) and glutathione S-transferase (GST) activities were done weighing $15 \mathrm{mg}$ kidney tissue for each group of rats and $1.5 \mathrm{ml}$ of an appropriate buffer for treating. An Qiagen tissue lyser LT homogeniser was used to homogenize the mixtures on ice in eppendorf tubes with steel balls for $15 \mathrm{~min}$. Then homogenates were filtered and centrifuged respectively in a refrigerated centrifuge at $4^{\circ} \mathrm{C}$. The supernatants were used to evaluate MDA, SOD, CAT, GPx and GST activities. All analyses were carried out at room temperature.

MDA Level: MDA as an end outcome of lipid peroxidation that reacts with thiobarbituric acid manufacturing thiobarbituric acid reactive substance (TBARS) was measured. After the occurring of a pink chromogen reaction, MDA level can be measured at $532 \mathrm{~nm}$ spectrophotometrically, an MDA standard to create a standard curve against which the sample readings were plotted was used. MDA level was expressed as $\mathrm{nmol} / \mathrm{min} / \mathrm{mg}$ tissue ${ }^{[21]}$.

SOD Activity: The SOD activity measurement was achieved according to the method proposed by Misra and Fridovich ${ }^{[22]}$ that depends on the generation of superoxide radicals. Superoxide radicals react with nitroblue tetrazolium (NBT) to form formazan dye, produced by the xanthine and xanthine oxidase system. The SOD activities of kidney tissues were identified at $560 \mathrm{~nm}$ by the degree of inhibition of NBT reaction. The activity of SOD was expressed as $\mathrm{mmol} / \mathrm{min} / \mathrm{mg}$ tissue.

CAT Activity: CAT activity was defined as the amount of CAT required to decompose 1 nmole of $\mathrm{H}_{2} \mathrm{O}_{2}$ per minute, at $25^{\circ} \mathrm{C}$ and $\mathrm{pH} 7.8$ and The kinetic analysis of the activity of CAT was started after the addition of $\mathrm{H}_{2} \mathrm{O}_{2}$ and at 240 $\mathrm{nm}$ the color reaction was measured ${ }^{[23]}$. CAT activity was expressed as $\mathrm{mmol} / \mathrm{min} / \mathrm{mg}$ tissue.

GPx Activity: GPx activity was measured according to the reaction between glutathione that remains after the action of 5, 5-dithiobis-(2-nitrobenzoic acid) and GPx to form a complex as IU/ $\mathrm{g}$ wet tissue that absorbs maximally at $412 \mathrm{~nm}{ }^{[24]}$. The activity of GPx of $1 \mathrm{U} / \mathrm{mg}$ was defined as $1 \mu \mathrm{g}$ of GSH consumed $\mu \mathrm{mol} / \mathrm{min} / \mathrm{g}$.

GST Activity: The GST activity was assayed according to the method of Habig detected by at $340 \mathrm{~nm}$ spectro- photometrically by using 1-chloro-2,4-dinitrobenzene with reduced glutathione which produces a dinitrophenyl thioether and GSH level was expressed as IU/min/g ${ }^{[25]}$.

\section{Histological Analysis}

The specimens were fixed in $10 \%$ buffered formalin solution for $72 \mathrm{~h}$, tissue processing for the conventional light microscopic technique examination was applied. Tissues were get from water to paraffin wax and sectioned $5 \mu \mathrm{m}$ thicknesses using a microtome (Leica RM2125RT, Germany). Sections were stained with Hematoxylin \& Eosin and photographed under a light microscope with a camera attachment (Nikon Eclipse E600, Japan).

\section{Statistical Analysis}

Biochemical parameter results (MDA, SOD, and etc.) were analyzed statistically using SPSS (IBM SPSS Statistics 18.0, IBM Corporation, Somers, NY, USA). Using one-way analysis of variance (abbreviated as one-way ANOVA) followed by Duncan test ( $P$ value $<0.05$ was determined as significant) the numerical data of groups were analyzed. The values were stated as mean \pm standard deviation.

\section{RESULTS}

\section{Biochemical Results}

Biochemical results revealed that there were significant differences between the control and the other experimental groups in the MDA levels of all groups $(P<0.05)$ and the experimental groups did not have significant differences with each other. Control group had the lowest MDA value when compared to other experimental groups. The SOD values were found higher in Control group and lower in Estrg group than in eccentric exercise and eccentric exercise plus in estrogen-given groups. The values of CAT were found higher in Control group and lower in Exc 1 group than estrogen-given and estrogen-given plus eccentric exercise groups. There was not any significant difference in terms of GPx and GST parameters in the experimental groups (Table 1).

\section{Histopathological Results}

Control Group: The medulla and cortex parenchyma and stroma were seen normal. The nephrons with Bowman's capsules and spaces, proximal and distal convoluted tubules, post tubular capillaries, Henle's loops, and collecting and papillary duct systems were seen in normal architecture. The connective tissue with its properties and the vessels' epithelium and their tunicas were determined normal (Fig. 2).

Estrg Group: There were scattered hemorrhagic foci in this group. The congested veins and peritubular capillaries were conspicuous. Spaces were detected near the some hemorrhagic foci. Vasoconstrictions in some arteries 
The Effect of Estrogen Treatment ...

Table 1. Statistical comparison between all studied biochemical parameters in the kidney tissues of all groups

Tablo 1. Tüm grupların böbrek dokularında çalışılan biyokimyasal parametrelerin istatistiki olarak karşılaştırılması

\begin{tabular}{|l|c|c|c|c|c|}
\hline Treatment & SOD $(\mathbf{m m o l} / \mathbf{m i n} / \mathbf{m g})$ & CAT $(\mathbf{m m o l} / \mathbf{m i n} / \mathbf{m g})$ & GST $(\boldsymbol{\mu m o l} / \mathbf{m i n} / \mathbf{g})$ & GPx $(I U / \mathbf{m i n} / \mathbf{g})$ & $\mathbf{M D A}(\mathbf{n m o l} / \mathbf{m i n} / \mathbf{m g})$ \\
\hline Control & $881.65 \pm 305.37^{\mathrm{a}}$ & $373.58 \pm 114.50^{\mathrm{a}}$ & $0.30 \pm 0.09^{\mathrm{a}}$ & $24.62 \pm 45.40^{\mathrm{a}}$ & $193.52 \pm 31.96^{\mathrm{c}}$ \\
\hline Estrg & $522.13 \pm 182.80^{\mathrm{c}}$ & $282.95 \pm 60.48^{\mathrm{b}}$ & $0.16 \pm 0.05^{\mathrm{a}}$ & $53.38 \pm 21.60^{\mathrm{a}}$ & $243.52 \pm 57.25^{\mathrm{b}}$ \\
\hline Exc 1 & $583.11 \pm 198.70^{\mathrm{b}}$ & $249.13 \pm 73.72^{\mathrm{c}}$ & $0.20 \pm 0.07^{\mathrm{a}}$ & $48.79 \pm 25.66^{\mathrm{a}}$ & $238.50 \pm 48.10^{\mathrm{b}}$ \\
\hline Estrg + Exc 1 & $563.52 \pm 306.78^{\mathrm{b}}$ & $312.11 \pm 104.93^{\mathrm{b}}$ & $0.28 \pm 0.12^{\mathrm{a}}$ & $52.63 \pm 25.24^{\mathrm{a}}$ & $482.64 \pm 127.22^{\mathrm{a}}$ \\
\hline Exc 48 & $608.60 \pm 205.85^{\mathrm{b}}$ & $293.21 \pm 95.45^{\mathrm{b}}$ & $0.24 \pm 0.17^{\mathrm{a}}$ & $80.61 \pm 54.46^{\mathrm{a}}$ & $421.88 \pm 110.99^{\mathrm{b}}$ \\
\hline Estrg + Exc 48 & $570.31 \pm 210.54^{\mathrm{b}}$ & $295.49 \pm 51.79^{\mathrm{b}}$ & $0.23 \pm 0.18^{\mathrm{a}}$ & $119.04 \pm 63.92^{\mathrm{a}}$ & $327.89 \pm 90.73^{\mathrm{b}}$ \\
\hline
\end{tabular}

Means in the same column by the same superscript letter are not statistically significantly different under the LSD test (P<0.05). Results are mean \pm standard deviation of the mean

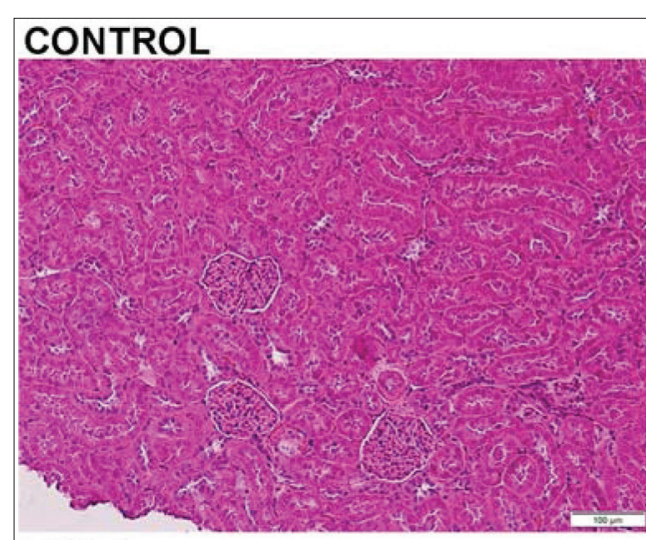

\section{EXC 1}

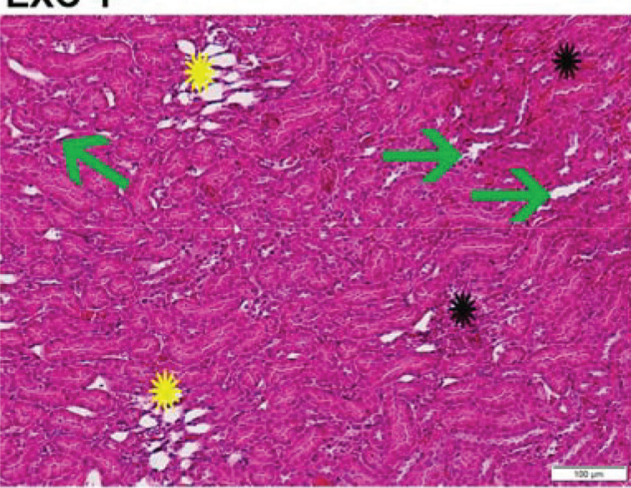

EXC 48

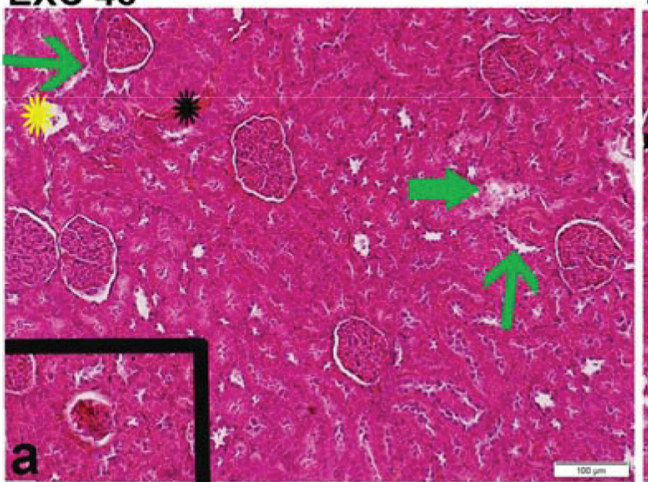

ESTRG



ESTRG+EXC 1

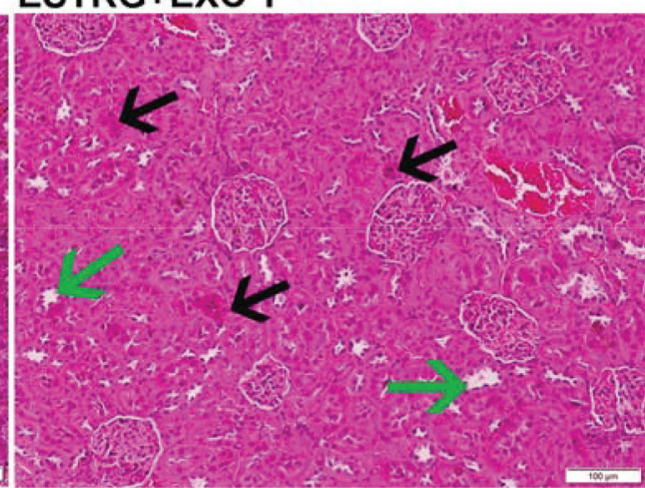

ESTRG+EXC 48

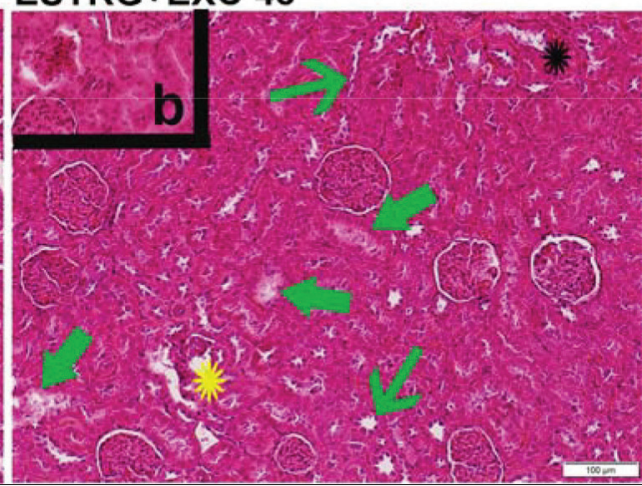

Fig 2. Micrograph of kidney tissue in lower magnification for all groups, black star- hemorrhage with fibrinated blood, yellow star- dilated peritubular capillaries, thin green arrow- dilated distal convoluted tubules, thin black arrowdegenerated proximal convoluted tubules, thick black arrow- narrowed bowman space that was hard to see, thick green arrow- degenerative areas in parenchyma, $a$ - a necrotic glomerulus, $b$ - a necrotic and hemorrhagic glomerulus, H\&E staining

Şekil 2. Tüm gruplarda böbrek dokularının mikroskopik görünümü, siyah yıldız- fibrinleşme ile beraber hemoraji, sarı yıldız- dilate olmuş peritübüler kılcal damarlar, ince yeşil ok- dilate olmuş distal kıvrımlı tübüller, ince siyah ok- dejenere olmuş proksimal kıvrımlı tübüller, kalın siyah ok- daralmiş, zor görülebilen bowman boşluğu, kalın yeşil ok- parankimde dejeneratif alanlar, $a$-nekrotik bir glomerül, $b$ - nekrotik ve hemorajik bir glomerül, H\&E boyama were distinguished and the walls of some veins were not conspicuous in which fibrinated blood was seen. Because of increasing in mesangium and dilatations and congestion in the capillaries of glomeruli, it was hard to see renal corpuscles and Bowman's spaces. Degenerative podocytes and proximal convoluted tubule cells were discriminated. The lumens of tubules were very narrow (Fig. 2).

Exc 1 Group: It was very distinctive to see the increasing congestions in veins and peritubular capillaries and 
degeneration areas in parenchyma. Renal corpuscles were seen with Bowman spaces. There were hemorrhagic foci like in the Estrg group, in that area, fibrinated blood was seen and there were increased fibrosis in peritubular area. There were necrotic podocytes, proximal convoluted cells and especially distal convoluted tubule cells with condensed nuclei. Distal convoluted tubule dilatations were detected, too. The most increased dilatations and disruptions in the epitheliums of peritubuler capillaries (they seem like clusters of spaces with dilated distal convoluted tubules) were distinguished in this group. PMNL infiltrations in the area of glomeruli and peritubular capillary dilatations were seen. The congestions and dilatations in the capillaries of glomeruli and increased mesangium were detected in this group, but also that was less than Group Estrg. There were degenerations in parietal layer cells and increasing in the connective tissue cells, too (Fig. 2).

Estr + Exc 1 Group: There were some hemorrhagic foci like in the Estrg and Exc groups. The dilatations in distal convoluted tubule were distinctive like in the Exc 1 group but it was less. There were scattered post capillary tubules' dilatations. Renal corpuscles were seen with Bowman spaces. Degenerative cells with eosinophilic cytoplasms and condensed nuclei in proximal convoluted tubule cells were clearly seen in this group than in other experimental groups. Degenerative cells in glomeruli were discriminated. The hemorrhage in glomeruli and peritubular capillaries were less than Estrg and Exc 1 groups. Degenerative podocytes were noticeable. The congestion in and fibrosis around of vessels were seen. There was PMNL infiltration and it was less than the Exc 1 group (Fig. 2).

Exc 48 Group: The Bowman spaces were seen. Many of the distal convoluted tubules were dispersed and post capillary tubules were dilated. A few necrotic glomeruli were detected differently (Fig. 2a) The hemorrhagic foci in this group were less and smaller than in Estrg and Esc 1 groups but also congestions and fibrinated blood were seen in some post capillary tubules. Disruptions in the epithelium of distal convoluted tubules and post capillary tubules were determined. Some degenerative areas were distinguished in parenchyma. The PMNL infiltrations in the area of glomeruli and peritubular capillary dilatations were seen like Exc 1 group (Fig. 2).

Estrg + Exc 48 Group: There were increased glomerular hemorrhage and necrotic glomeruli in this group (Fig. 2b). Dispersed hemorrhagic foci were seen, too. Degenerative areas in parenchyma like Exc 48 group were detected, but also decreased degenerations in tubular cells were distinguished. In addition, dilatations and fibrinated bloods in veins and post tubular capillaries were seen (Fig. 2).

\section{DISCUSSION}

Regular exercise has been confirmed as a countermeasure to defend and control against cardiac injury, diabetes, mental health and etc ${ }^{[26-29]}$. On the other hand, acute, intense or prolonged exercises have been stated as a risk factor for infertility, damaging bone structure or others ${ }^{[30,31]}$. There are also many stated harmful effects of these types of exercises such as abruptly rise in blood plasma calcium concentrations, developing of fatal hyponatremia, reducing in the number of lymphocytes and suppressing the natural killer cells' functions in that immunodepression time micro-organisms can pass the first line of defence ${ }^{[31-33]}$. Variety of studies have revealed that acute physical exercise can trigger a stress response and significant pathological changes, comprising cell apoptosis in the tissues of the distant organs, such as kidney, liver and intestine as well as in working skeletal muscles. During intense exercise, some organs including kidney undergo partial ischemia that causes reducing in the blood supply, after that, tissue reoxygenation and excessive production of ROS occur ${ }^{[34,35]}$. Through the oxidative stress, apoptosis of various cell types can occur ${ }^{[36]}$. In previous studies it has been concluded that the apoptosis of the distal tubular and collecting duct cells occur in rat kidney tissues as a response to the acute exercise ${ }^{[37]}$ and intense exercise cause proteinuria and biochemical changes in proximal convoluted tubules ${ }^{[38]}$. Several defence mechanisms have been demonstrated to decrease the ROS concentration, including both antioxidant enzymes (SOD, CAT, and GPx) and non-enzymatic agents (GSH) in intense exercise- induced kidney tissues ${ }^{[37]}$. Otherwise endothelium-dependent vasodilatations can occur via increasing production of oxidative stress in humans ${ }^{[39-41]}$.

Estrogen is an important agent for the anti-inflammatory and antithrombotic roles. In addition, estrogen may cause vasomotor dysfunction that is a possible cause for triggering of plaque rupture ${ }^{[42]}$. It has been observed in as little as $15 \mathrm{~min}$ an acute improvement endotheliumdependent vasodilation occurred in vascular tissues after estrogen treatment that could be related with interaction of the classic steroid-hormone receptor ${ }^{[43]}$. Estrogen treatment has not only effects the endothelium but also involves extracellular matrix, vascular smooth muscle, and the establishment of collaterals ${ }^{[44,45]}$. Stumpf et al. ${ }^{[46]}$ have detected estrogen receptors are in interstitial cells, glomeruli and proximal tubule cells in kidney tissues. Estrogen binds to specific cytoplasmic and nuclear receptors ${ }^{[16,47]}$. Faroqui et al. ${ }^{[48]}$ reported that the management of estrogen to postmenopausal women is related with hypophosphatemia which is associated with a reducing in phosphate reabsorption in the proximal tubules.

In this study, the biochemical results revealed that decreases in antioxidant enzymes' activities in Exc 1 or Estrg groups. These results could be associated with acute effects of intense exercise that cause reducing in blood supply, partial ischemia, that give rise to the more production of ROS in Exc 1 group and degenerations in responsive tissues to estrogen like interstitial cells, glomeruli and proximal tubule cells via cytoplasmic or 
nuclear receptors' interactions in Estrg group. The MDA levels in all experimental groups were significantly higher than in control group, and Estrg+Exc 1 group had the highest value. That could be related to the acute effect of estrogen and exercise together. In histological results in experimental groups except control group hemorrhage occurred but it was more in estrogen-given and estrogengiven plus eccentric exercise group. Hemorrhage could occur due to the antithrombotic effects of estrogen or an acute development of endothelium-dependent vasodilation and alterations in connective tissue due to the response to estrogen. The most dilatation in distal convoluted tubule neighboring peritubular capillaries dilatations that were seen like clusters of spaces and significantly degenerations in distal tubule cells occurred in the Exc 1 group. These results could be related with to the apoptosis of distal tubular cells rejection to acute exercise and the endothelium-dependent vasodilatations through the increased oxidative stress in peritubular capillaries in Exc 1. The most degenerative proximal tubules in Estrg + Exc 1 were discriminated that could be associated with estrogen receptors in proximal tubules triggering molecular alterations via oxidative stress. The PMNL infiltrations were less in Estrg + Exc 1 and Estrg + Exc 48 groups than in the Exc 1 and Exc 48 groups, respectively, and these results had accordance with SOD and CAT activities of Estrg and Exc 1 groups, respectively. Decrease in antioxidant enzymes' activities indicate oxidative stress process in which PMNL infiltration occur. These results had also revealed that the role of anti-inflammatory effect of estrogen. The other distinctive results; there were increased degenerative areas in parenchyma and necrotic renal corpuscles in Exc 48 and especially in Estrg + Exc 48 groups that showed prolonged effects of estrogen and exercise together on kidney tissues could cause damages in parenchyma tissue.

In conclusion, this current study was carried out to examine the role of estrogen on eccentic exercise-induced rat kidney tissue. The researches on this issue are limited. The results of this study indicated that estrogen (since it leads to decreases in PMNL infiltration in estrogen-given plus eccentric exercise groups) could play anti-inflammatory role on eccentric exercise-induced rat kidney tissues in short or long period. On the other hand, hemorrhage and endothelium-depended vasodilatations in estrogen given and estrogen-given plus eccentric exercise groups occurred. Dilatations of distal and peritubular capillaries in especially Exc 1 group revealed acute effect of hypoxemia via oxidative stress. Degenerations of distal and proximal convoluted tubule cells and renal corpuscles showed that prolonged effects of estrogen and exercise together on kidney. The current study's results force us to think about whether estrogen had any therapeutic effect or not on clinical practice. It has been requested further investigation to examine with other histological methods such as immunohistochemical and stereological methods and other biochemical methods such as studying related oxidative stress parameters.

\section{REFERENCES}

1. Gleeson M: Immune function in sport and exercise. J Appl Physiol, 103, 693-699, 2007. DOI: 10.1152/japplphysiol.00008.2007

2. Swardfager W, Herrmann N, Cornish S, Mazereeuw G, Marzolini S, Sham L, Lanctôt KL: Exercise intervention and inflammatory markers in coronary artery disease: A meta-analysis. Am Heart J, 163, 666-676, e3, 2012. DOI: 10.1016/j.ahj.2011.12.017

3. Hu FB, Manson JE, Stampfer MJ, Colditz G, Liu S, Solomon CG, Willett WC: Diet, lifestyle, and the risk of type 2 diabetes mellitus in women. N Engl J Med, 345, 790-797, 2001. DOI: 10.1056/NEJMoa010492

4. Heiwe S, Jacobson SH: Exercise training for adults with chronic kidney disease. The Cochrane Library, 2011. DOI: 10.1002/14651858.CD003236. pub2

5. Grondard C, Biondi O, Armand A-S, Lécolle S, Della Gaspera B, Pariset C, Li H, Gallien CL, Vidal PP, Chanoine C, Charbonnier F: Regular exercise prolongs survival in a type 2 spinal muscular atrophy model mouse. J Neurosci, 25, 7615-7622, 2005. DOI: 10.1523/jneurosci. 1245-05.2005

6. Benito B, Gay-Jordi G, Serrano-Mollar A, Guasch E, Shi Y, Tardif J-C, Brugada J, Nattel S, Mont L: Cardiac arrhythmogenic remodeling in a rat model of long-term intensive exercise training. Circulation, 123, 13-22, 2011. DOI: 10.1161/CIRCULATIONAHA.110.938282

7.Kumaş C, Maden M: Evaluation of the dynamic (overground) endoscopy procedure in the diagnosis of upper respiratory tract diseases affecting performance of racehorses. Kafkas Univ Vet Fak Derg, 19 (Suppl. A): A55-A60, 2013. DOI: 10.9775/kvfd.2012.7707

8. Castenfors J: Renal function during prolonged exercise. Ann NY Acad Sci, 301, 151-159, 1977. DOI: 10.1111/j.1749-6632.1977.tb38194.x

9. Schrier RW, Hano J, Keller HI, Finkel RM, Gilliland PF, Cirksena WJ, Teschan PE: Renal, metabolic, and circulatory responses to heat and exercise: Studies in military recruits during summer training, with implications for acute renal failure. Ann Intern Med, 73, 213-223, 1970. DOI: 10.7326/0003-4819-73-2-213

10. Nussey SS, Whitehead SA: Endocrinology: An Integrated Approach. CRC Press, 2013.

11. Saruhan BG, Sagsoz H, Ketani MA, Akbalik ME, Ozyurtlu N: Immunohistochemical detection of estrogen and progesteron receptors in the bovine uterus and their relation to serum sex steroid hormone levels during the follicular and luteal phase. Kafkas Univ Vet Fak Derg, 15, 447-454, 2009. DOI: 10.9775/kvfd.2009.039-A

12. Keskin A, Öner $Y$, Yilmazbaş-Mecitoğlu G. Distributions of CYP19, ERa and PGR allele frequencies between fertile and subfertile Holstein-Friesian heifers. Kafkas Univ Vet Fak Derg, 21, 893-898, 2015. DOI: 10.9775/kvfd.2015.13827

13. Darabi M, Ani M, Panjehpour M, Rabbani M, Movahedian A, Zarean E: Effect of estrogen receptor $\beta$ A1730G polymorphism on ABCA1 gene expression response to postmenopausal hormone replacement therapy. Genet Test Mol Biomarkers, 15, 11-15, 2011. DOI: 10.1089/ gtmb.2010.0106

14. Rosano G, Panina G: Oestrogens and the heart. Therapie, 54, 381385, 1998.

15. Nadkarni S, Cooper D, Brancaleone V, Bena S, Perretti M: Activation of the annexin A1 pathway underlies the protective effects exerted by estrogen in polymorphonuclear leukocytes. Arterioscler Thromb Vasc Biol, 31, 2749-2759, 2011. DOI: 10.1161/ATVBAHA.111.235176

16. Roy D, Liehr JG: Estrogen, DNA damage and mutations. Mutat Res Fund Mol Mech Mut, 424, 107-115. 1999. DOI: 10.1016/S00275107(99)00012-3

17. Andersen HL, Weis JU, Fjalland B, Korsgaard N: Effect of acute and long-term treatment with 17-beta-estradiol on the vasomotor responses in the rat aorta. Br J Pharmacol, 126, 159-168, 1999.

18. Koot RW, Amelink GJ, Blankenstein MA, Bar PR: Tamoxifen and 
estrogen both protect the rat muscle against physiological damage. $J$ Steroid Biochem, 40, 689-695, 1991.

19. Kenagy R, Weinstein I, Heimberg M: The effects of 17-beta-estradiol and progesterone on the metabolism of free fatty-acid by perfused livers from normal female and ovariectomized rats. Endocrinology, 108, 16131621, 1981. DOI: 10.1210/endo-108-5-1613

20. Tsivitse SK, McLoughlin TJ, Peterson JM, Mylona E, McGregor SJ, Pizza FX. Downhill running in rats: Influence on neutrophils, macrophages, and MyoD+ cells in skeletal muscle. Eur J Appl Physiol, 90, 633-638, 2003. DOI: 10.1007/s00421-003-0909-0

21. Ohkawa $\mathbf{H}$, Ohishi N, Yagi K: Assay for lipid peroxides in animal tissues by thiobarbituric acid reaction. Anal Biochem, 95, 351-358, 1979 DOI: 10.1016/0003-2697(79)90738-3

22. Misra HP, Fridovich I: The role of superoxide anion in the autoxidation of epinephrine and a simple assay for superoxide dismutase. J Biol Chem 247, 3170-3175, 1972.

23. Aebi H: Catalase in vitro. Method Enzymol, 105, 121-126, 1984.

24. Chiu DT, Stults FH, Tappel AL: Purification and properties of rat lung soluble glutathione peroxidase. Acta Biochem Biophys-Enzymol, 445, 558-566, 1976. DOI: 10.1016/0005-2744(76)90110-8

25. Habig WH, Pabst MJ, Jakoby WB: Glutathione S-transferases. The first enzymatic step in mercapturic acid formation. J Biol Chem, 25, 249 (22): 7130-7139, 1974.

26. Ascensão A, Ferreira R, Magalhães J: Exercise-induced cardioprotection-biochemical, morphological and functional evidence in whole tissue and isolated mitochondria. Int J Cardiol, 117, 16-30, 2007. DOI: 10.1016/j.ijcard.2006.04.076

27. Rosenthal M, Haskell W, Solomon R, Widstrom A, Reaven GM: Demonstration of a relationship between level of physical training and insulin-stimulated glucose utilization in normal humans. Diabetes, 32, 408-411, 1983. DOI: 10.2337/diab.32.5.408

28. Emery CF, Blumenthal JA: Effects of physical exercise on psychological and cognitive functioning of older adults. Ann Behav Med, 13 (3): 1991, 99-107, 1991.

29. Kull M: The relationships between physical activity, health status and psychological well-being of fertility-aged women. Scand J Med SCi Spor, 12, 241-247, 2002. DOI: 10.1034/j.1600-0838.2002.00341.x

30. Green BB, Daling JR, Weiss NS, Liff JM, Koepsell T: Exercise as a risk factor for infertility with ovulatory dysfunction. Am J Public Health, 76, 1432-1436, 1986. DOI: 10.2105/AJPH.76.12.1432

31. Ruben JA, Bennett AF: Intense exercise, bone structure and blood calcium levels in vertebrates, Nature, 291, 411-413, 1981. DOI: 10.1038/ 291411a0

32. Noakes TD, Norman RJ, Buck RH, Godlonton J, Stevenson K, Pittaway D: The incidence of hyponatremia during prolonged ultraendurance exercise. Med Sci Sports, 22, 165-170, 1990.

33. Pedersen BK, Bruunsgaard H: How physical exercise influences the establishment of infections. Sports Med, 19, 393-400, 1995. DOI: 10.2165/00007256-199519060-00003

34. Bobillier Chaumont S, Maupoil V, Jacques Lahet J, Berthelot A:
Effect of exercise training on metallothionein levels of hypertensive rats. Med Sci Sports, 33, 724-728, 2001. DOI: 10.1097/00005768-20010500000007

35. Bonnet F, Cao Z, Cooper ME: Apoptosis and angiotensin II: Yet another renal regulatory system? Exp Nephrol, 9, 295-300, 2000. DOI: $10.1159 / 000052624$

36. Gwinner W, Grone HJ: Role of reactive oxygen species in glomerulonephritis. Nephrol Dial Transpl, 15, 1127-1132, 2000. DOI: 10.1093/ ndt/15.8.1127

37. Podhorska-Okolow M, Dziegiel P, Dolinska-Krajewska B, Dumanska M, Cegielski M, Jethon Z, Rossini K, Carraro U, Zabel M: Expression of metallothionein in renal tubules of rats exposed to acute and endurance exercise. Folia Histochem Cytobiol, 44, 195-200, 2006.

38. Poortmans J, Blommaert E, Baptista M, De Broe M, Nouwen E: Evidence of differential renal dysfunctions during exercise in men. Eur J Appl Physiol, 76, 88-91, 1997. DOI: 10.1007/s004210050217

39. Goto C, Higashi Y, Kimura M, Noma K, Hara K, Nakagawa K: Effect of different intensities of exercise on endothelium-dependent vasodilation in humans role of endothelium-dependent nitric oxide and oxidative stress. Circulation, 108, 530-535, 2003.

40. Wang J, Wolin MS, Hintze TH: Chronic exercise enhances endothelium-mediated dilation of epicardial coronary artery in conscious dogs. Circ Res, 73, 829-38, 2003. DOI: 10.1161/01.RES.73.5.829

41. Delp MD, McAllister RM, Laughlin MH: Exercise training alters endothelium-dependent vasoreactivity of rat abdominal aorta. J Appl Phys, 75, 1354-1363, 1993.

42. Gerhard M, Ganz P: How do we explain the clinical benefits of estrogen? From bedside to bench. Circulation, 92, 5-8, 1995. DOI: 10.1161/01.CIR.92.1.5

43. Gilligan DM, Quyyumi AA, 3rd Cannon RO: Effects of physiological levels of estrogen on coronary vasomotor function in postmenopausal women. Circulation, 89, 2545-2551, 1994. DOI: 10.1161/01.CIR.89.6.2545

44. Jiang CW, Sarrel PM, Lindsay DC, Poole-Wilson PA, Collins P: Endothelium-independent relaxation of rabbit coronary artery by 17 beta-oestradiol in vitro. $\mathrm{Br} J$ Pharmacol, 104, 1033-1037, 1991. DOI: 10.1111/j.1476-5381.1991.tb12545.x

45. Jiang C, Sarrel PM, Poole-Wilson PA, Collins P: Acute effect of 17 beta-estradiol on rabbit coronary artery contractile responses to endothelin-1. Am J Physiol, 263, 271-275, 1992.

46. Stumpf WE, Sar M, Narbaitz R, Reid FA, DeLuca HF, Tanaka Y: Cellular and subcellular localization of 1, 25-(OH) 2-vitamin D3 in rat kidney: Comparison with localization of parathyroid hormone and estradiol. Proc Natl Acad Sci USA, 77, 1149-1153, 1980.

47. Smith SS: Female sex steroid hormones: From receptors to networks to performance--actions on the sensorimotor system. Prog Neurobiol, 44, 55-86, 1994. DOI: 10.1016/0301-0082(94)90057-4

48. Faroqui S, Levi $\mathbf{M}$, Soleimani $\mathbf{M}$, Amlal H: Estrogen downregulates the proximal tubule type lla sodium phosphate cotransporter causing phosphate wasting and hypophosphatemia. Kidney Int, 73, 1141-1150, 2008. DOI: 10.1038/ki.2008.33 